\section{Bispyribac-sodium, Sulfosulfuron, and Interseeding Creeping Bentgrass for Long-term Control of Roughstalk Bluegrass}

\author{
James M. Rutledge ${ }^{1,5}$, Debbie E. Morton², Daniel V. Weisenberger ${ }^{3}$, \\ and Zachary J. Reicher ${ }^{4}$ \\ Purdue University, Department of Agronomy, Lilly Hall of Life Science, 915 \\ West State Street, West Lafayette, IN 47907-2054 \\ Additional index words. Poa trivialis, interseeding, certainty, velocity
}

\begin{abstract}
Roughstalk bluegrass (Poa trivialis L.) contamination is problematic on golf course fairways from the Midwest to the mid-Atlantic regions of the United States. Bispyribac-sodium and sulfosulfuron have potential to selectively control roughstalk bluegrass. Our objectives were to determine the most effective herbicide treatments for short- and long-term roughstalk bluegrass control and to determine if interseeding with creeping bentgrass (Agrostis stolonifera $\mathrm{L}$.) after herbicide treatments will improve longterm control of roughstalk bluegrass or conversion to creeping bentgrass. Plots were treated with bispyribac-sodium or sulfosulfuron and then half of each plot was interseeded with creeping bentgrass in early August, 2 weeks after the final herbicide application in 2006, 2007, and 2008 in Indiana. Roughstalk bluegrass cover reduction was highest when treated with bispyribac-sodium at 56 or $74 \mathrm{~g} \cdot \mathrm{ha}^{-1}$ a.i. applied four times or sulfosulfuron at $27 \mathrm{~g} \cdot \mathrm{ha}^{-1}$ a.i. applied three times. Interseeding with creeping bentgrass improved long-term roughstalk bluegrass control and quickened conversion to creeping bentgrass. Furthermore, bispyribac-sodium and sulfosulfuron appeared to be more effective in the first 2 years of the study when seasonal heat stress was greater, which appeared to improve long-term roughstalk bluegrass control and promoted creeping bentgrass establishment. Chemical names used: $\{2,6$-bis [(4,6-dimethoxypyrimidin-2-yl)oxy] benzoic acid $\}$ (bispyribac-sodium), \{1-[4,6-dimethoxypyrimidin-2-yl]-3-[2-ethanesulfonylimidazo(1,2-a)pyridine-3-yl) sulfonyl]urea\} (sulfosulfuron).
\end{abstract}

Roughstalk bluegrass (Poa trivialis L.; RBG) contamination is problematic on creeping bentgrass (Agrostis stolonifera L.; CBG) fairways from the Midwest to the mid-Atlantic regions of the United States. Roughstalk bluegrass has poor drought and heat tolerance; thus, turf areas with substantial RBG populations thin in late summer, decreasing aesthetic and functional quality (Christians, 2004). Selective herbicide control is valuable because cultural management of RBG has not been effective (Weisenberger and Reicher, 2006). However, thin or bare areas remain after large patches of RBG are treated and these areas are open to reinfestation of RBG or other weeds. Roughstalk bluegrass is stoloniferous and thus complete control of stolons is difficult. Therefore, interseeding CBG soon after herbicide application could help repopulate these bare areas and compete with other weeds or surviving RBG.

Two selective herbicides that control RBG in CBG are bispyribac-sodium $\{2,6$-bis[ $[(4,6-$

Received for publication 14 Oct. 2009. Accepted for publication 16 Nov. 2009.

${ }^{1}$ Graduate Research Assistant.

${ }^{2}$ Dow AgroScience Sales Representative.

${ }^{3}$ Research Agronomist.

${ }^{4}$ Professor.

${ }^{5}$ To whom reprint requests should be addressed; e-mail jrutledg@purdue.edu. dimethoxypyrimidin-2-yl)oxy] benzoic acid (BYS) and sulfosulfuron \{1-[4,6-dimethoxypyrimidin-2-yl]-3-[2-ethanesulfonyl-imidazo (1,2-a)pyridine-3-yl) sulfonyl]urea (SULFO). Bispyribac-sodium is labeled for use in turfgrass as Velocity ${ }^{\mathrm{TM}}$ (Valent U.S.A. Corp., Walnut Creek, CA) and SULFO is labeled for use in turfgrass as Certainty ${ }^{\mathrm{TM}}$ (Monsanto, St. Louis, MO). Our previous research has shown that SULFO and BYS effectively control RBG (Morton et al., 2007; Rutledge et al., 2009). For instance, BYS at 56 or 74 $\mathrm{g} \cdot \mathrm{ha}^{-1}$ a.i. applied four times on 2-week intervals decreased RBG cover by greater than $85 \% 12$ weeks after initial treatment (WAIT) at one location, whereas SULFO at $27 \mathrm{~g} \cdot \mathrm{ha}^{-1}$ a.i. reduced RBG cover by $34 \% 8$ WAIT at another location (Morton et al., 2007). In a 2-year study conducted in Virginia, three applications of BYS at $37 \mathrm{~g} \cdot \mathrm{ha}^{-1}$ a.i. starting in June, August, or September reduced RBG 10 WAIT by $88 \%, 48 \%$, and $11 \%$, respectively, and increasing the rate to $74 \mathrm{~g} \cdot \mathrm{ha}^{-1}$ a.i. resulted in $93 \%, 95 \%$, and $31 \%$ control, respectively (Askew et al., 2004). Because CBG can be safely seeded within 2 to 4 weeks of either BYS or SULFO application (Lycan and Hart, 2005, 2006; Rutledge et al., 2009), our objectives were to determine the most effective herbicide treatments for shortand long-term RBG control and to determine if interseeding with $\mathrm{CBG}$ after herbicide treatments will improve long-term control of RBG and conversion to CBG.

\section{Materials and Methods}

Treatments were initiated in June 2006, 2007, and 2008 at the W.H. Daniel Turfgrass Research and Diagnostic Center, West Lafayette, IN. The experimental area was 'Laser' RBG originally seeded at $98 \mathrm{~kg} \cdot \mathrm{ha}^{-1}$ in Aug. 2004 and had less than $10 \%$ contamination of CBG on initiation of the study. Soil type was a Starks-Fincastle silt loam (fine-silty, mixed, mesic Aeric Ochraqualf) with a $\mathrm{pH}$ of 7.2 and organic matter content of $3.8 \%$. Treatments were arranged in a split-plot design with eight herbicide treatments as main plots and two seeding treatments as subplots. Main plots were $3 \times 1.5 \mathrm{~m}$ with $0.5-\mathrm{m}$ untreated alleyways between each main plot and subplots measured $1.5 \times 1.5 \mathrm{~m}$. Herbicide treatments were selected based on previous studies (Morton et al., 2007) and are listed in Table 1. All herbicide applications were applied in $814 \mathrm{~L} \cdot \mathrm{ha}^{-1}$ water with a $\mathrm{CO}_{2}$-pressurized backpack sprayer using a three-nozzle (TeeJet XR8001.5VS; Spraying Systems Co., Wheaton, IL) boom at $207 \mathrm{kPa}$. Throughout the experiment, turf received $196 \mathrm{~kg}$ nitrogen/ha/year and was irrigated to ensure optimal growth before interseeding CBG and to encourage germination after seeding CBG. Turf was mowed three times per week at 1.25 $\mathrm{cm}$ and clippings were returned. Fungicides were applied preventatively on 28-d intervals for dollar spot (Sclerotinia homeocarpa), brown patch (Rhizoctonia solani), and pythium (Pythium spp.) control beginning in June and ending in August of each year.

One half of each main plot was seeded 2 weeks after the final herbicide application with 'L 93' CBG at $49 \mathrm{~kg} \cdot \mathrm{ha}^{-1}$ on 10,10 , and 12 Aug. of 2006, 2007, and 2008, respectively (Table 1). Sixty-four grams of $6 \mathrm{~N}-0 \mathrm{P}-1.7 \mathrm{~K}$ organic fertilizer (Milorganite, Milwaukee, WI) was added to the seed as a bulking material and then shaken onto plots by hand with shaker bottles. The seedbed was prepared by aerating the entire experimental area with $0.64-\mathrm{cm}$ diameter solid tines using a ride-on aerifier with $5 \times 5-\mathrm{cm}$ tine spacing. After emergence, plots continued to be mowed three times per week at $1.25 \mathrm{~cm}$ and clippings were returned. Initial seeding was not successful in 2007 as a result of above average heat and disease pressure, and the area was reseeded on 5 Sept. 2007 in the same manner as previously described.

Percent cover of $\mathrm{CBG}$ and $\mathrm{RBG}$ was visually estimated every 2 weeks from midJune to mid-November of each year. We present percent cover in early August, 2 weeks after treatment (WAT) as an indication of short-term herbicide effects before $\mathrm{CBG}$ germination, 16 WAT in November was before winter, and 46 WAT in July of the next year was after spring recovery to gauge long-term control. Data were analyzed using PROC MIXED (SAS Institute, Cary, NC). Data were arcsine-transformed and individual $t$ tests were used to separate means. Error 
Table 1. Herbicide application dates for 2006, 2007, and 2008.

\begin{tabular}{|c|c|c|c|c|}
\hline Herbicide $^{z}$ & Rate (g/a.i. ha/app) ${ }^{y}$ & 2006 & 2007 & 2008 \\
\hline$\overline{S U L F O}^{x}$ & 13 & 13 July, 27 July & 12 July, 27 July & 15 July, 29 July \\
\hline SULFO & 27 & 13 July, 27 July & 12 July, 27 July & 15 July, 29 July \\
\hline SULFO & 27 & 29 June, 13 July, 27 July & 29 June, 12 July, 27 July & 1 July, 15 July, 29 July \\
\hline BYS & 56 & 15 June, 29 June, 13 July, 27 July & 15 June, 29 June, 12 July, 27 July & 17 June, 1 July, 15 July, 29 July \\
\hline BYS & 74 & 15 June, 29 June, 13 July, 27 July & 15 June, 29 June, 12 July, 27 July & 17 June, 1 July, 15 July, 29 July \\
\hline Untreated control & - & - & - & \\
\hline
\end{tabular}

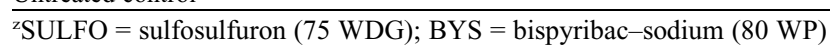

${ }^{y}$ Applied every 2 weeks.

${ }^{x}$ All SULFO treatments included MON 0818 nonionic surfactant at $0.25 \% \mathrm{v} / \mathrm{v}$.

Table 2. Analysis of variance for percent cover of roughstalk bluegrass and creeping bentgrass in 2006, 2007, and $2008 .^{\mathrm{z}}$

\begin{tabular}{|c|c|c|c|c|c|c|c|c|c|}
\hline & \multicolumn{3}{|c|}{2006} & \multicolumn{3}{|c|}{2007} & \multicolumn{3}{|c|}{2008} \\
\hline & $2 \mathrm{WAT}^{\mathrm{y}}$ & 16 WAT & $46 \mathrm{WAT}$ & $2 \mathrm{WAT}$ & $16 \mathrm{WAT}$ & $46 \mathrm{WAT}$ & $2 \mathrm{WAT}$ & $16 \mathrm{WAT}$ & $46 \mathrm{WAT}$ \\
\hline \multicolumn{10}{|l|}{ Roughstalk bluegrass } \\
\hline Seed & - & NS & $* *$ & - & NS & ** & - & NS & NS \\
\hline Seed $\times$ herbicide & - & NS & NS & - & NS & NS & - & NS & NS \\
\hline \multicolumn{10}{|l|}{ Creeping bentgrass } \\
\hline Herbicide & NS & * & ** & NS & NS & NS & NS & NS & NS \\
\hline
\end{tabular}

${ }^{\mathrm{z}}$ Data were arcsine-transformed for analysis.

${ }^{\mathrm{y}} \mathrm{WAT}=$ weeks after treatment.

Ns, * **Nonsignificant or significant at $P \leq 0.05$ or 0.01 , respectively.

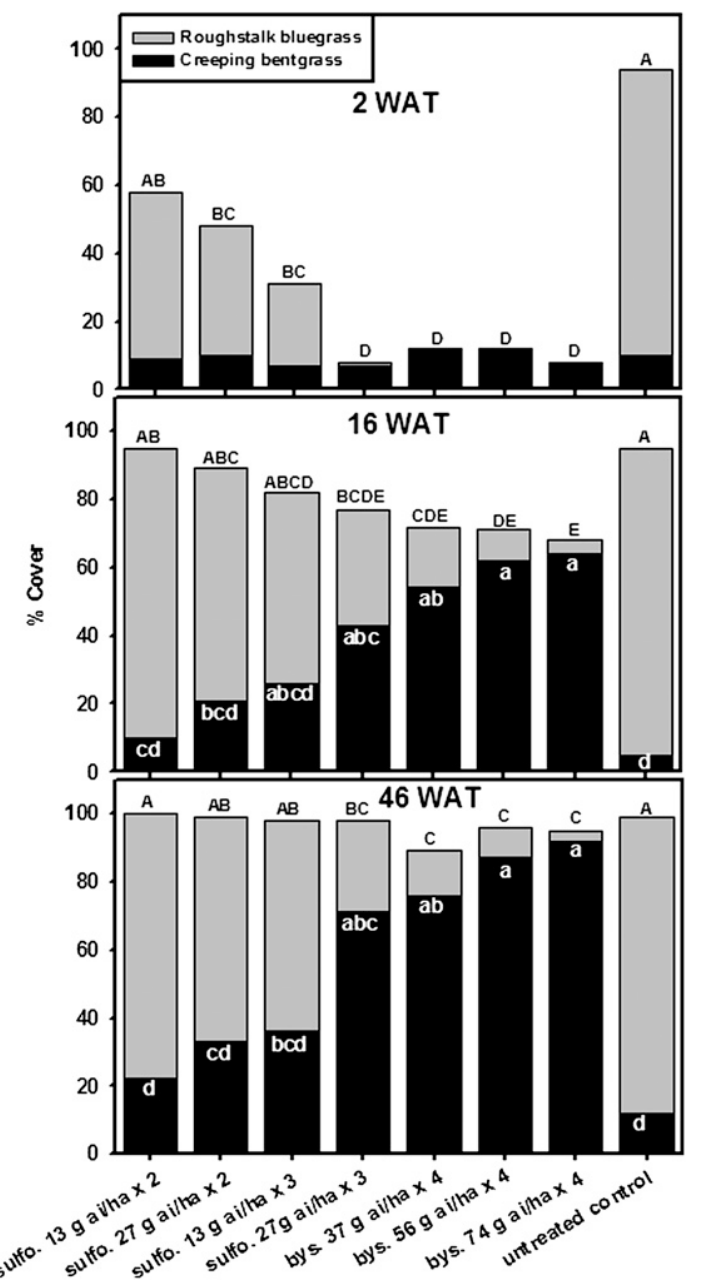

Fig. 1. Roughstalk bluegrass and creeping bentgrass cover as a result of sulfosulfuron (sulfo) and bispyribac-sodium (bys) 2, 16, and 46 weeks after treatment (WAT) in 2006. Means are back-transformed and averaged across three replications. Lower case letters are used to compare creeping bentgrass cover, whereas upper case letters are used to compare roughstalk bluegrass cover. Bars with the same letter and case within the same rating date are not significantly different $(P<0.05)$.

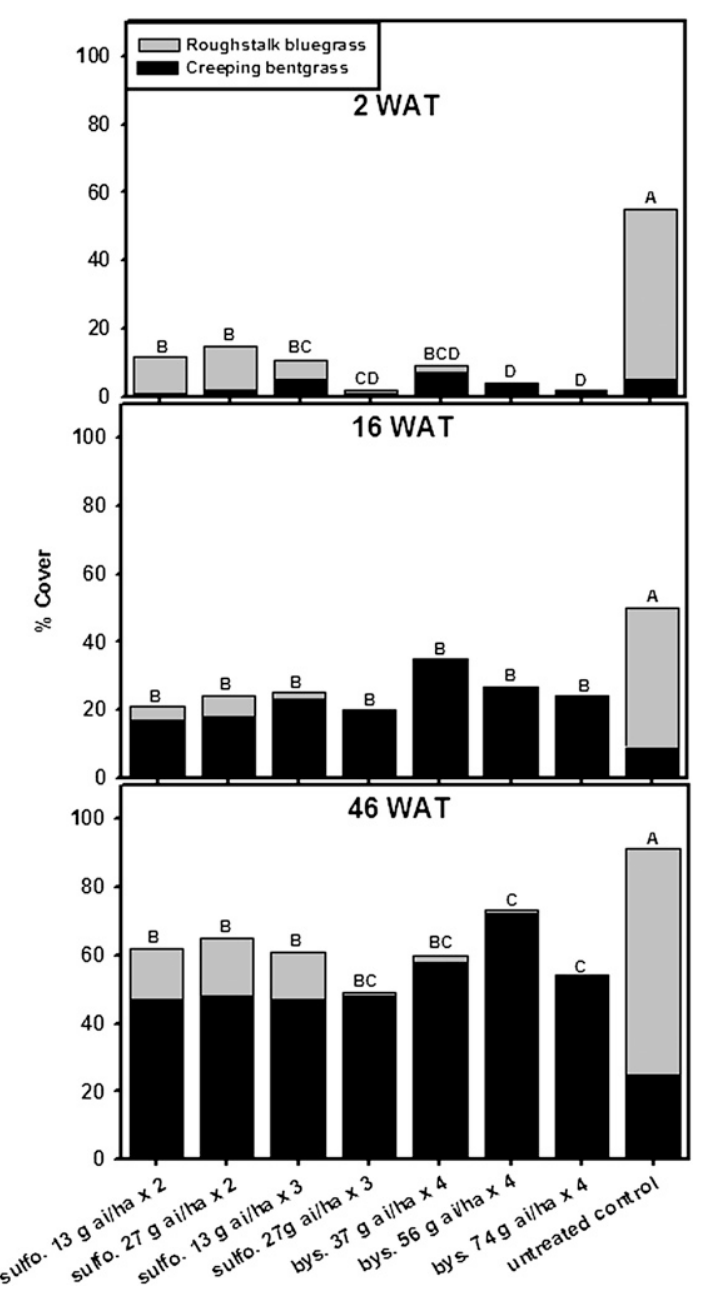

Fig. 2. Roughstalk bluegrass and creeping bentgrass cover as a result of sulfosulfuron (sulfo) and bispyribac-sodium (bys) 2, 16, and 46 weeks after treatment (WAT) in 2007. Means are back-transformed and averaged across three replications. Letters compare roughstalk bluegrass cover. Bars with the same letter within the same rating date are not significantly different $(P<0.05)$. 
variances were not homogenous, and thus data were not combined across years.

\section{Results and Discussion}

Impact of herbicides. All herbicide treatments applied in 2006 reduced RBG cover to $50 \%$ or less 2 WAT compared with the untreated control, which retained $83 \%$ cover (Table 2; Fig. 1). Sulfosulfuron at $27 \mathrm{~g} \cdot \mathrm{ha}^{-1}$ a.i. applied three times and BYS at 37,56 , or $74 \mathrm{~g} \cdot \mathrm{ha}^{-1}$ a.i. applied four times were the most effective treatments in controlling RBG, resulting in $1 \%$ or less cover 2 WAT in 2006 (Fig. 1). Of these four treatments, plots that received SULFO at $27 \mathrm{~g} \cdot \mathrm{ha}^{-1}$ a.i. applied three times or BYS at $37 \mathrm{~g} \cdot \mathrm{ha}^{-1}$ a.i. applied four times recovered to between $5 \%$ and $40 \%$ RBG cover 16 WAT. Recovery was likely the result of spread from uncontrolled stolons and indicates the need for long-term control data on RBG. These same four treatments remained most effective through 46 WAT reducing RBG cover to $27 \%$ or less compared with $87 \%$ in the untreated control (Fig. 1). Treatments most effective in controlling RBG also resulted in the most CBG cover. Averaged over seeding treatments in 2006, plots treated with SULFO at $27 \mathrm{~g} \cdot \mathrm{ha}^{-1}$ a.i. or BYS at 37,56 , or $74 \mathrm{~g} \cdot \mathrm{ha}^{-1}$ a.i. had $43 \%$ or greater CBG cover 16 WAT and $71 \%$ or greater CBG cover by 46 WAT compared with the untreated control with $5 \%$ and $12 \%$ CBG cover 16 and 46 WAT, respectively (Fig. 1).

Overall RBG cover 2 WAT was much lower in 2007 than in 2006 with all herbicide treatments in 2007 reducing RBG cover to $13 \%$ or less 2 WAT compared with the untreated control with 50\% RBG cover (Fig. 2). This is likely the result of higher temperatures in 2007 and is consistent with our anecdotal observations that SULFO and BYS more effectively control RBG when it is heatstressed after applications (Fig. 3) (Loveys et al., 2002; Sifers and Beard, 1993). When exposed to heat stress in 2007, all herbicide treatments reduced RBG cover to $6 \%$ or less compared with $41 \%$ in the untreated control 16 WAT. Despite this, the same four treatments, SULFO at $27 \mathrm{~g} \cdot \mathrm{ha}^{-1}$ a.i. and all three BYS treatments, remained the most effective RBG controls (Fig. 2). However, modest RBG recovery occurred by 46 WAT with cover remaining $17 \%$ or less in treated plots compared with $66 \%$ in the untreated control (Fig. 2).

Three of the four best performing treatments in 2006 and 2007 also performed well in 2008. Sulfosulfuron applied three times at $27 \mathrm{~g} \cdot \mathrm{ha}^{-1}$ a.i. and BYS applied four times at 56 or $74 \mathrm{~g} \cdot \mathrm{ha}^{-1}$ a.i. reduced RBG cover to between $10 \%$ and $45 \%$ compared with $83 \%$ cover in the untreated control 2 WAT (Fig. 4). However, RBG cover after all herbicide

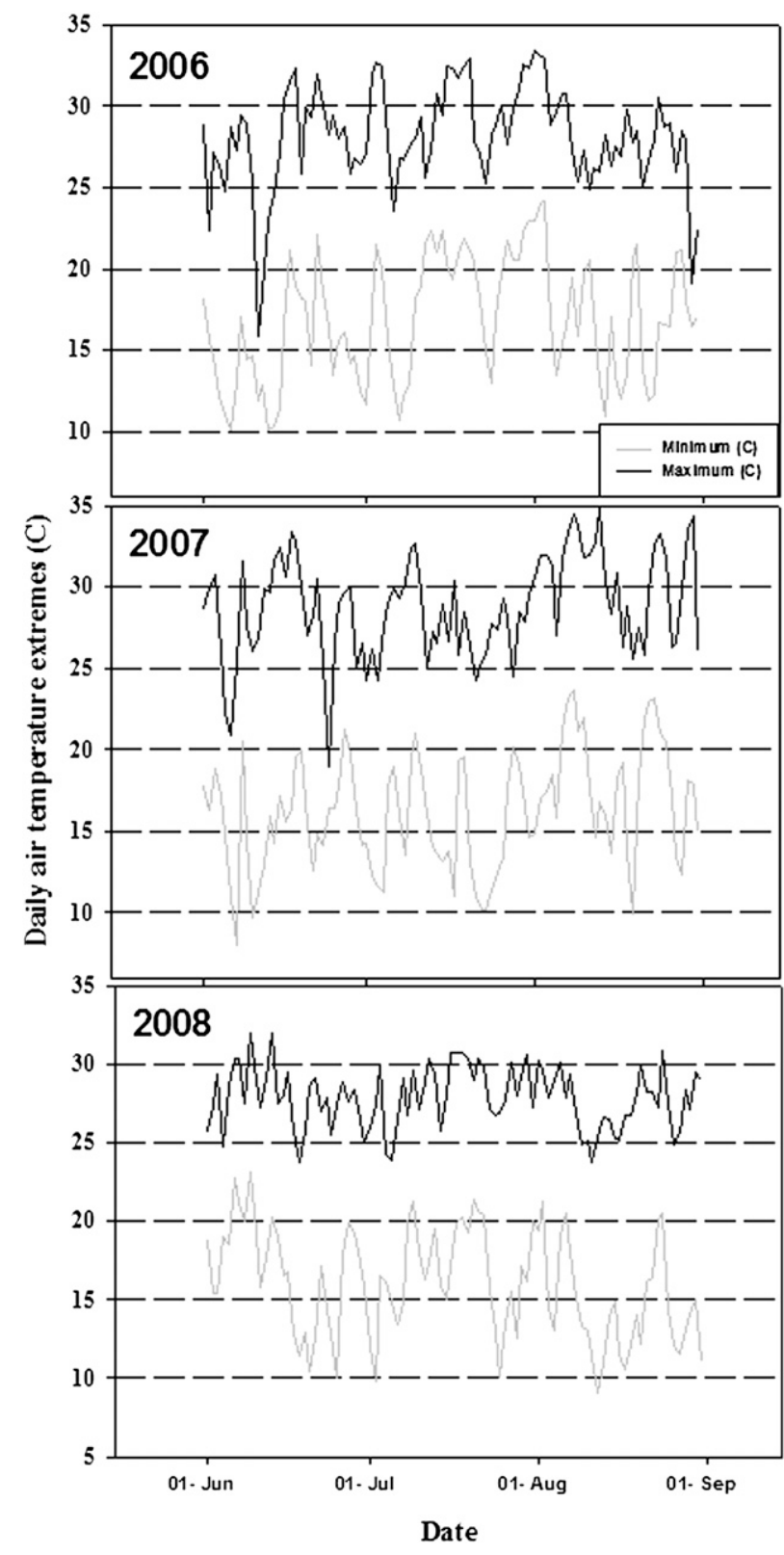

Fig. 3. Minimum and maximum daily air temperatures in West Lafayette, IN, from 1 June to 1 Sept. 2006, 2007, and 2008.

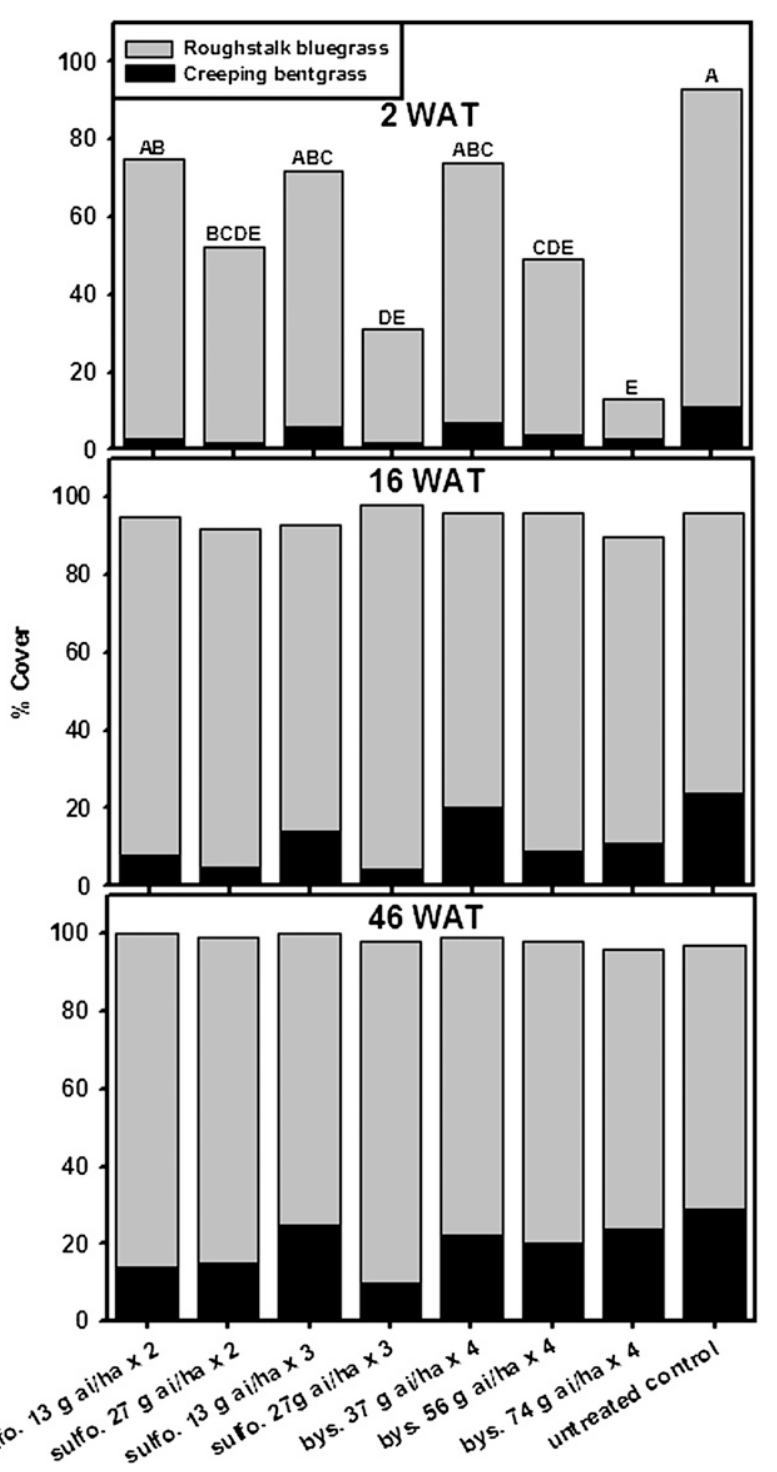

Fig. 4. Roughstalk bluegrass and creeping bentgrass cover as a result of sulfosulfuron (sulfo) and bispyribac-sodium (bys) 2, 16, and 46 weeks after treatment (WAT) in 2008. Means are back-transformed and averaged across three replications. Letters compare roughstalk bluegrass cover. Bars with the same letter within the same rating date are not significantly different $(P<$ $0.05)$. 
treatments fully recovered to equal that of the untreated control by 16 WAT (Fig. 4). We attribute the lack of RBG control to an unseasonably cool summer in 2008 when RBG experienced minimal stress and was able to fully recover after herbicide treatments (Fig. 3). Between 1 June and 1 Sept. in West Lafayette, IN, there were a total of 21, 28 , or $7 \mathrm{~d}$ on which the maximum air temperature exceeded $30^{\circ} \mathrm{C}$ in 2006,2007 , or 2008, respectively (Fig. 3). In addition to the number of days above $30{ }^{\circ} \mathrm{C}$, we also witnessed an apparent relationship between RBG damage and the number of consecutive days with high temperatures exceeding $30{ }^{\circ} \mathrm{C}$ or low temperature exceeding $20^{\circ} \mathrm{C}$. Daily high temperatures remained above $30^{\circ} \mathrm{C}$ for more than 3 consecutive days on four, five, or one occasion(s) in 2006, 2007, and 2008, respectively, of which 2006, 2007, and 2008 had a maximum of 6,9 , and 3 consecutive days above $30^{\circ} \mathrm{C}$, respectively (Fig. 3). Daily minimum temperatures followed similar trends with temperatures remaining above $20{ }^{\circ} \mathrm{C}$ more often and for longer durations in 2006 and 2007 than in 2008 (Fig. 3). This yearly variation in temperature likely contributed to the differing RBG control observed in

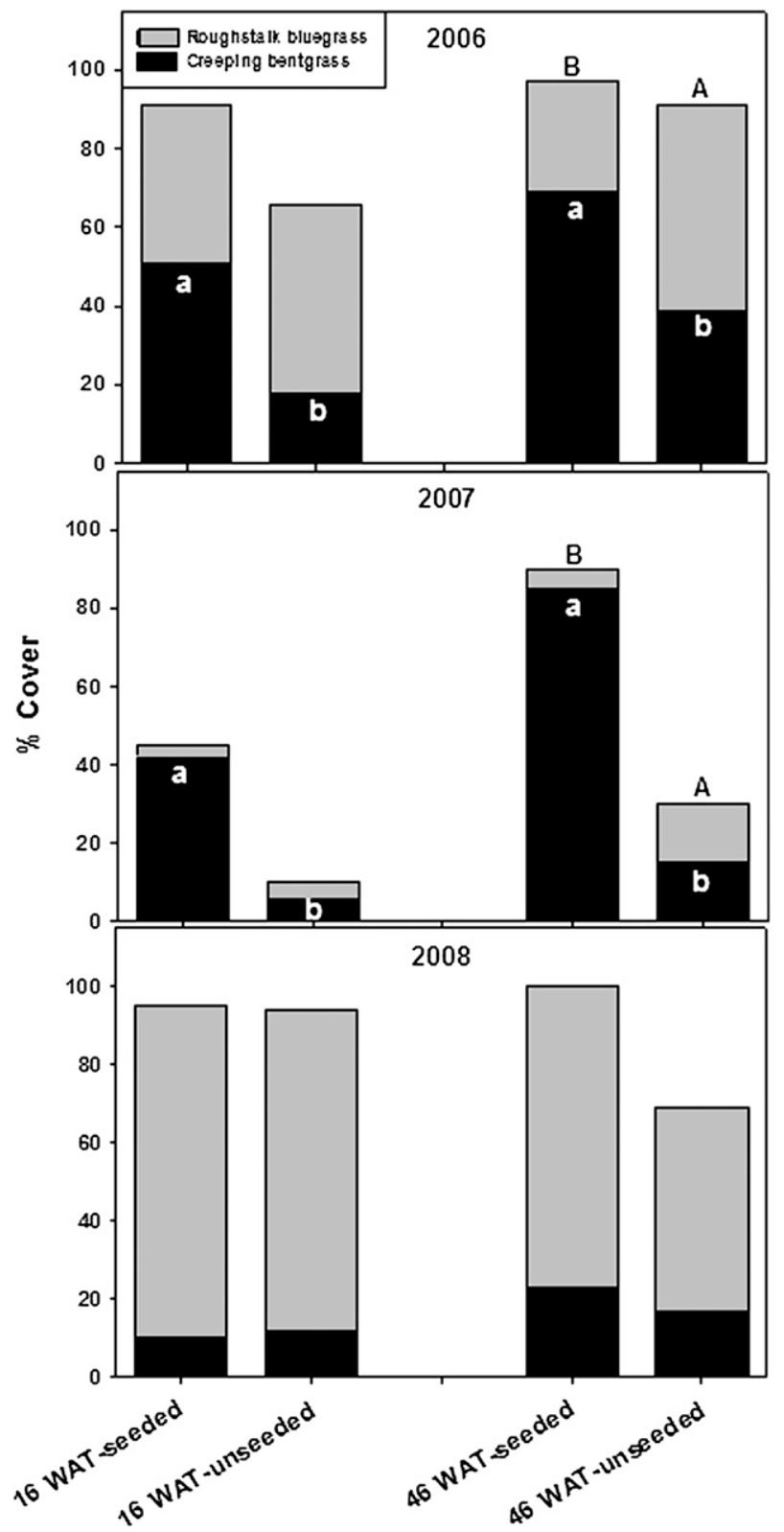

Fig. 5. Roughstalk bluegrass and creeping bentgrass cover 16 and 46 weeks after treatment (WAT) as a result of creeping bentgrass seeding treatments in 2006, 2007, and 2008. Means are back-transformed and are over eight herbicide treatments and three replications. Lower case letters are used to compare creeping bentgrass cover, whereas upper case letters are used to compare roughstalk bluegrass cover. Bars with the same letter and case within the same rating date are not significantly different $(P<0.05)$ each of the 3 years, with exceptional RBG control being achieved in 2007 and minimal control in 2008. This further confirms our anecdotal observations that environmental stress compliments herbicide activity, which results in better control and supports our observation that stolons likely contribute to the regeneration of $\mathrm{RBG}$ after herbicide treatment. Our observations of RBG response to BYS when compounded by summer stress coincide with those of annual bluegrass ( $\mathrm{Poa}$ annua L.). McCullough and Hart (2006) reported that BYS efficacy on annual bluegrass increased as temperatures increased from 10 to $30^{\circ} \mathrm{C}$.

Impact of seeding. Averaged across herbicide treatments, plots seeded with $\mathrm{CBG}$ had less RBG cover than unseeded plots 46 WAT in 2006 and 2007 (Fig. 5) but had no affect on RBG cover 16 WAT in either year (Table 2 ). This indicates interseeding with $\mathrm{CBG}$ is advantageous for long-term RBG control, but CBG must become well-established before it can pose formidable competition to RBG. Averaged across herbicide treatments, seeded plots had $51 \%$ or $42 \%$ CBG cover 16 WAT compared with $18 \%$ or $6 \%$ in unseeded plots in 2006 or 2007, respectively (Fig. 5).

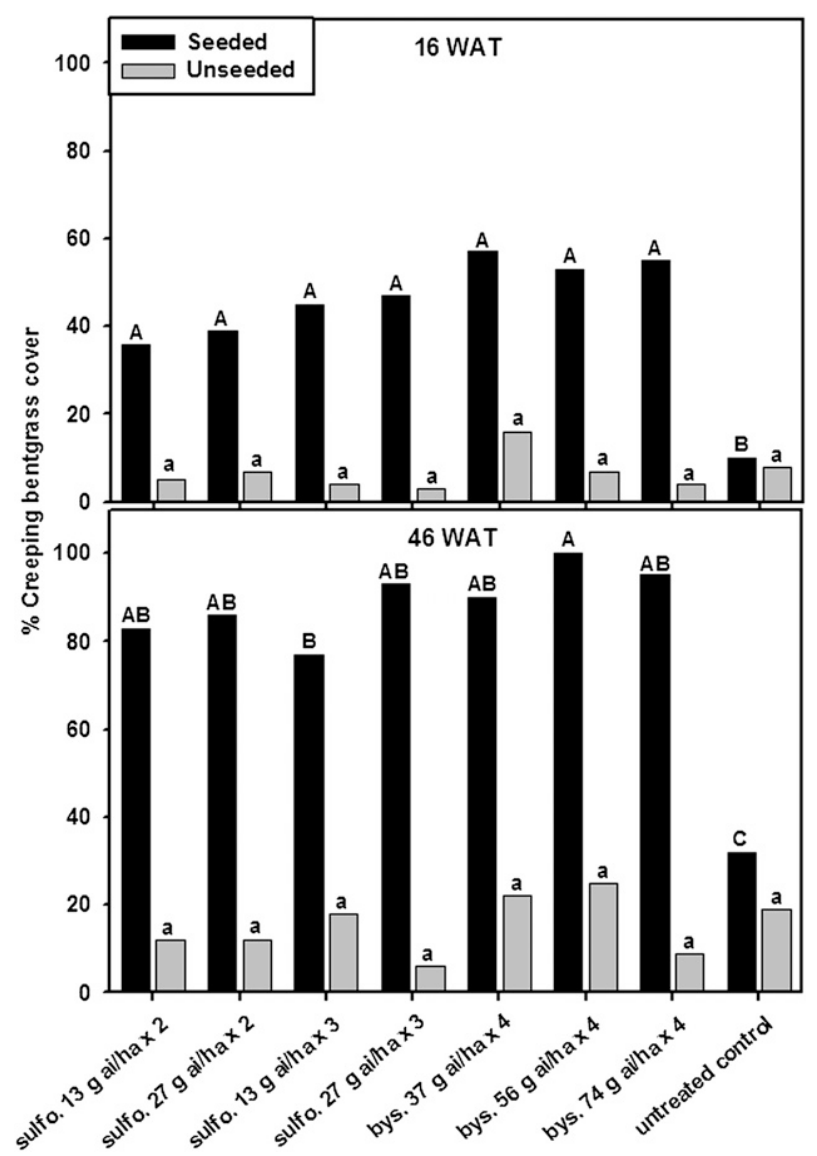

Fig. 6. Creeping bentgrass cover as a result of sulfosulfuron (sulfo) and bispyribac-sodium (bys) and two seeding treatments 16 and 46 weeks after treatment (WAT) in 2007. Means are back-transformed and are over three replications. Lower case letters are used to compare unseeded treatments, whereas upper case letters are used to compare seeded treatments. Bars with the same letter are not significantly different $(P<0.05)$. 
By 46 WAT, seeded plots had $69 \%$ or $85 \%$ CBG cover compared with $39 \%$ or $15 \%$ CBG cover in unseeded plots in 2006 or 2007, respectively (Fig. 5). Creeping bentgrass in unseeded plots was primarily the result of prior contamination, which spread quickly with reduced competition from RBG after herbicide applications. Seeding did not affect CBG cover 16 or 46 WAT in 2008 as a result of rapid RBG recovery after herbicide treatments (Fig. 5).

A significant seed $\times$ herbicide interaction occurred in CBG cover 16 and 46 WAT in 2007 (Table 2; Fig. 6). Minimal CBG established in untreated plots regardless of interseeding, likely resulting from competition from $\mathrm{RBG}$, which retained $41 \%$ cover in the untreated control in 2007 (Fig. 2). These results are similar to those observed by Gaussoin and Branham (1989) in which there was little to no change in CBG cover after interseeding 'Penncross' CBG without a previous herbicide application in a mixed annual bluegrass (Poa annua L.)/CBG stand.

\section{Conclusions}

The most effective herbicide treatments for RBG control were BYS at 56 or $74 \mathrm{~g} \cdot \mathrm{ha}^{-1}$ a.i. applied four times or SULFO at $27 \mathrm{~g} \cdot \mathrm{ha}^{-1}$ a.i. applied three times. Although these herbicides control RBG and will allow CBG already present in the treated areas to spread, interseeding with CBG will improve long-term RBG control and speed conversion to $\mathrm{CBG}$. Furthermore, BYS and SULFO appeared to be more effective in the first 2 years of the study when seasonal heat stress was greater, which appeared to improve long-term RBG control and promoted CBG establishment.

\section{Literature Cited}

Askew, S.D., J.B. Beam, D.S. McCall, W.L. Barker, H.B. Couch, and J.R. Chamberlin. 2004. Annual bluegrass, roughstalk bluegrass, and dollar spot control with bispyribac-sodium. Proc. Northeast Weed Sci. Soc. 58:124-126.

Christians, N. 2004. Fundamentals of turfgrass management. John Wiley and Sons, Inc., Hoboken, NJ.

Gaussoin, R. and B.E. Branham. 1989. Influence of cultural factors on species dominance in a mixed stand of annual bluegrass/creeping bentgrass. Crop Sci. 29:480-484.

Loveys, B.R., I. Scheurwater, T.L. Pons, A.H Fitter, and O.K. Atkin. 2002. Growth temperature influences the underlying components of relative growth rate: An investigation using inherently fast- and slow-growing plant species. Plant Cell Environ. 25:975-988.
Lycan, D.W., and S.E. Hart. 2005. Cool-season turfgrass reseeding intervals for sulfosulfuron. Online. Appl. Turfgrass Sci. doi: 10.1094/ ATS-2005-0808-01-RS.

Lycan, D.W. and S.E. Hart. 2006. Cool-season turfgrass reseeding intervals for bispyribacsodium. Weed Technol. 20:526-529.

McCullough, P.E. and S.E. Hart. 2006. Temperature influences creeping bentgrass (Agrostis stolonifera) and annual bluegrass (Poa annua) response to bispyribac-sodium. Weed Technol. 20:728-732.

Morton, D., D. Weisenberger, Z. Reicher, B. Branham, B. Sharp, R. Gaussoin, J. Stier, and E. Koeritz. 2007. Evaluating bispyribacsodium and sulfosulfuron for control of roughstalk bluegrass. HortScience 42:1710-1714.

Rutledge, J.M., D.V. Weisenberger, and Z.J. Reicher. 2009. Effect of sulfosulfuron on 'Penncross' creeping bentgrass seedlings when applied before or after seeding. Online. Appl. Turfgrass Sci. doi: 10.1094/ATS-2009-071001-RS.

Sifers, S.I. and J.B. Beard. 1993. Comparative inter- and intra- specific leaf firing resistance to supraoptimal air and soil temps in coolseason turfgrass genotypes. Intl. Turfgrass Soc. Res. J. 7:621-628.

Weisenberger, D.V. and Z.J. Reicher. 2006. Effect of season-long fungicide programs on survival of Poa trivialis. 2006 Purdue turfgrass research summary. 6 Aug. 2009. <http://www.agry.purdue. edu/turf/report/2006/45.pdf $>$. 